\title{
Ethylene production and acc oxidase gene expression during fruit ripening of Coffea arabica $\mathrm{L}$.
}

\author{
Luiz Filipe Protasio Pereira ${ }^{1 *}$, Rafaelo M. Galvão ${ }^{2}$, Adilson K. Kobayashi ${ }^{3}$, Sandra Maria B. Cação ${ }^{2}$ and Luiz \\ Gonzaga Esteves Vieira ${ }^{2}$
}

${ }^{1}$ Embrapa Café - Lab. Biotecnologia Vegetal-IAPAR, CP 481, 86001-970, Londrina PR, Brazil; ${ }^{2}$ Área de Melhoramento e Genética, IAPAR, CP 481, 86001-970, Londrina PR, Brazil; ' ${ }^{3}$ mbrapa Mandioca e Fruticultura, CP 007, 44380-000; Cruz das Almas BA, Brazil; *Corresponding author:lpereira@iapar.br.

Received: 05/04/2005, Accepted: 10/09/2005

The phytohormone ethylene is involved in several physiological and developmental processes in higher plants, including ripening of fruits, abscission of organs and tissues, senescence, wound response as well as in other abiotic stresses. The enzyme 1-aminocyclopropane-1-carboxylate oxidase (ACO) catalyzes the last step of ethylene biosynthesis. The production of ethylene and the expression of a Coffea arabica ACO gene during the last stages of fruit maturation were investigated. A rapid increase of ethylene production at the green-yellow stage of fruit ripening, after the end of endosperm formation, and a decrease of ethylene production at the cherry stage indicates a climacteric phase during ripening. An $A C C$ oxidase $(C a-A C O)$ from coffee fruit cDNA was cloned and characterized using primers previously reported. The cDNA is homologous to previously described ACC oxidase cDNA in Coffea. The nucleotide and amino acid deduced sequences of the clone showed high homology with ACO from climacteric fruits. Northern blots were performed to determine the $C a-A C O$ transcription pattern from different tissues and from fruits at different ripening stages. Coffee fruits at an early ripening stage (green) showed the lowest level of $\mathrm{Ca}$ $A C O$ transcript accumulation. The transcript levels of $C a-A C O$ did not change significantly during the later stages, suggesting the presence of post- transcriptional control mechanisms. These results, taken together, strongly suggest a climacteric nature of coffee fruit ripening.

Key words: ACC oxidase, climacteric, coffee, ethylene, maturation.

Produção de etileno e expressão do gene de ACC-oxidase durante a maturação de frutos de Coffea arabica L.: O fitormônio etileno está associado a vários eventos fisiológicos e etapas de desenvolvimento da plantas. A enzima 1-aminociclopropano-1carboxilato oxidase (ACO) catalisa o último passo da biossíntese desse fitormônio. Neste trabalho, estudou-se a produção de etileno durante a maturação de frutos de café, assim como a expressão do gene de ACC oxidase de cafeeiro durante a maturação e em diferentes órgãos da planta. Verificou-se rápido crescimento na produção de etileno em frutos verde-cana, após o final da formação do endosperma, com um decréscimo nos frutos-cereja, indicando uma fase climatérica na maturação. Usando oligonucleotídeos previamente descritos, efetuou-se a clonagem e caracterização de um gene de $A C O$ de $C$. arabica $(C a-A C O)$. A seqüência de nucleotídeos, assim como a de aminoácidos, demonstrou alta similaridade com ACO de frutos climatéricos. O padrão de transcrição gênica de $C a$ - $A C O$ em frutos em diferentes fases de maturação e em diferentes tecidos foi analisado em Northern Blots. Frutos verdes apresentaram a menor transcrição de $C a-A C O$, com um aumento a partir dos frutos verdecana, havendo pouca alteração nas etapas subseqüentes de maturação, sugerindo a atuação de mecanismos de controle póstranscricionais. Os resultados indicam a natureza climatérica da maturação dos frutos de café.

Palavras-chave: ACC oxidase, café, etileno, maturação. 


\section{INTRODUCTION}

Quality in coffee has been associated with the ripening stage of the fruits during harvest time, among other factors. In plantations where there is good rainfall distribution, flowering can occur over a long period, resulting in uneven fruit ripening (Rena et al., 1994; Majerowicz and Söndahl, 2005). Furthermore, the use of high-density cultivation can also contribute for less synchronized fruit ripening. Environmental and planting system conditions associated with poor harvest and post-harvest practices result in a low quality product, decreasing the coffee cup quality (Browning and Fisher, 1976; Camargo et al., 1985). The presence of green fruits and over-ripened fruits changes the acidity, the bitterness and consequently the quality of the product. In order to avoid this, coffee-berries must be picked manually or post-harvest selected, which involves increased costs due to extra manual labor or the acquisition of special machinery.

One way to improve fruit ripening is to control the action of genes involved in the last steps of the maturation process, which is triggered by ethylene. Ethylene is involved in several physiological processes in plants, such as the response to biotic and abiotic environmental stresses (Yang and Hoffman, 1984; Wang et al., 2002). This phytohormone plays a key role in senescence of organs and tissues, fruit ripening and abscission. In climacteric fruits, a dramatic increase in ethylene biosynthesis promotes the subsequent steps of fruit ripening, involving biochemical and physiological changes. These changes include: softening of the cell wall, sugar accumulation, modification of phenolic and organic acid compounds, accumulation of anthocyanins and carotenoids. The ethylene burst stimulates an increase in respiration, which provides the necessary energy for such metabolic changes. According to Yang (1987), there are three major enzymes controlling the biosynthesis of ethylene. Initially, S-adenosylmethionine synthase converts methionine to S-adenosyl-L-methionine (SAM), which is converted into 5 'methyladenosine and 1-aminocyclopropane-1-carboxylic (ACC) acid by ACC synthase (ACS). ACC is the precursor of ethylene. The last step in ethylene biosynthesis is catalyzed by 1-aminocyclopropane-1-carboxylic acid oxidase (ACO), which converts ACC into ethylene. Genes of ACO have already been isolated in several species, including tomato (Hamilton et al., 1990), melon (Balagué et al., 1993), tobacco (Knoester et al., 1995) and papaya (Lin et al., 1997). They are generally present as a small and very conserved gene family. Expression of ACO genes can be regulated by environmental, developmental or tissue specific factors (Whittaker et al., 1997; Lopez-Gomez et al., 2004; Song et al., 2005).
In Coffea, the identification of ACC synthase and oxidase genes has been reported (Neupane et al., 1999; Stiles et al., 1999), but the characterization of ethylene production and its correlation with $A C O$ transcription during fruit maturation were not reported. Our overall goal was to study and characterize the genes and the biochemical changes occurring during coffee fruit ripening, which could enable the development of strategies to improve the uniformity of fruit maturation in coffee plants, and consequently the quality of the product. In this paper, we describe the production of ethylene in coffee fruits at different ripening stages, the cloning and characterization of an $A C O$ and its transcription pattern related to ethylene levels during fruit maturation.

\section{MATERIAL AND METHODS}

Ethylene analysis: Fruits of Coffea arabica L. cv IAPAR 59 were collected and separated according to their ripening stage based on the color of the fruits, after full endosperm formation, that is: green, yellow-red, red, cherry and darkcherry. Twenty-four fruits from each maturation stage were separated and placed in $250 \mathrm{~mL}$ airtight flask for $4 \mathrm{~h}$ (eight fruits per flask). Ethylene production was measured by taking $1 \mathrm{~mL}$ gas samples with subsequent analysis by Gas Chromatography (Hewlett Packard 6890 GC). Three measurements were performed for each ripening stage. Data were analyzed using Fischer's protected LSD (0.05).

Cloning of ACC oxidase: Total RNA was isolated from fruit pulp at the initial stages of ripening (yellow-red and red) according to Chang et al. (1993). One $\mu \mathrm{g}$ of total RNA was used to produce cDNA using the Amersham First Strand T-primed Kit. Two primers from the flanking region from a coffee $A C O$ sequence (Stiles et al., 1999) were used to amplify the cDNA: 5'-AAGAGAGATGGCTACATTCC-3', and 5'-CTCAAACAGTTGGCATTGGACC-3', in the sense and antisense orientations, respectively. PCR reactions were performed with $200 \mu \mathrm{M}$ of each dNTP, $10 \mathrm{mM}$ Tris-HCl, 5.0 $\mathrm{mM} \mathrm{MgCl} 2,50 \mathrm{mM} \mathrm{KCl}, 1.5 \mathrm{U}$ Taq polymerase and 25-50 ng of template cDNA. PCR conditions were $4 \mathrm{~min}$ at $94^{\circ} \mathrm{C}$, followed by 30 cycles of $1 \mathrm{~min}$ at $94^{\circ} \mathrm{C}, 1 \mathrm{~min}$ at $46^{\circ} \mathrm{C}, 2 \mathrm{~min}$ at $72^{\circ} \mathrm{C}$ and a final cycle of $5 \mathrm{~min}$ at $72^{\circ} \mathrm{C}$ in a thermocycler PTC- $100^{\mathrm{TM}}$ (MJ Research, Walthan, MA, USA). PCR products were visualized in $1 \%$ agarose gels and stained with ethidium bromide. The amplified DNA fragment was purified using the Concert ${ }^{\mathrm{TM}}$ Rapid Gel Extraction System (Invitrogen, Carlsbad, CA, USA), cloned into the Sma I site of the pUC18 vector using the SureClone ${ }^{\mathrm{TM}}$ Ligation 
Kit (Amersham Biosciences, San Francisco, CA, USA) and sequenced by the Sanger method using the automated sequencer MegaBACE DNA Analysis Systems.

Similarity search was performed using BLAST - Basic Local Alignment Search Tool (Altschul et al., 1990) at GenBank/NCBI. Sequences with most similarities were separated and aligned with ClustalW (Thompson et al., 1994) at http://clulstalw.genome.jp, to produce both a phylogenetic dendrogram and the alignment for protein motif search. The protein motifs were identified using the Eukariotic Linear Motif program at http://elm.eu.org/ (Puntervoll et al., 2003).

Southern and Northern blot analysis: For Southern blot analysis, $10 \mu \mathrm{g}$ of DNA were digested overnight with 5 units of EcoRI and resolved by electrophoresis. The DNA was transferred to nylon membranes and hybridized with the ACC oxidase cDNA $(\mathrm{Ca}-\mathrm{ACO})$ clone labeled with $\mathrm{dCTP}^{32}-\alpha$ using a random primer method. Hybridization was performed overnight at $65^{\circ} \mathrm{C}$ with $2 \mathrm{XSSC}, 1 \% \mathrm{SDS}$, 5XDenhardt's solution and $100 \mu \mathrm{g} . \mathrm{mL}^{-1}$ denatured salmon sperm DNA. The membranes were washed as follows: 2XSSC at room temperature for $5 \mathrm{~min} ; 2 \mathrm{X}$ SDS and $1 \%$ SDS at $42^{\circ} \mathrm{C}$ for $30 \mathrm{~min}$; and $0.2 \mathrm{XSSC}$ and $1 \%$ SDS for 5 $\mathrm{min}$ at room temperature. Membranes were exposed for two to three days to X-Omat Kodak film with an intensifying screen. For Northern blot analysis, $10 \mu \mathrm{g}$ of total RNA was transferred to nylon membranes and hybridized as described above using UltraHyb solution (Ambion). For the loading control, blots were hybridized with a partial coffee 18S rRNA probe cloned in our lab using the primers: 5'-AACGGATACCACATCCAAGG-3', and 5'CCGAAGGCCAACACAATAGG-3', in the sense and antisense orientation, respectively.

\section{RESULTS AND DISCUSSION}

The ethylene produced in green fruits was very low, with a dramatic increase at the initial stages of ripening (figure 1). During the final stages of fruit ripening, especially at the cherry stage and with overripe fruits, a decrease of ethylene concentration was observed. Similar results were observed in a second experiment carried out one year later, using fruits collected from the same coffee field. An increase in ethylene production at initial stages of maturation is associated with climacteric-type fruits. Although it is still not clear what controls the initial levels of ethylene production, its synthesis is autocatalytic, stimulating a burst of ethylene during the initial stages of ripening which is characteristic of climacteric fruits.

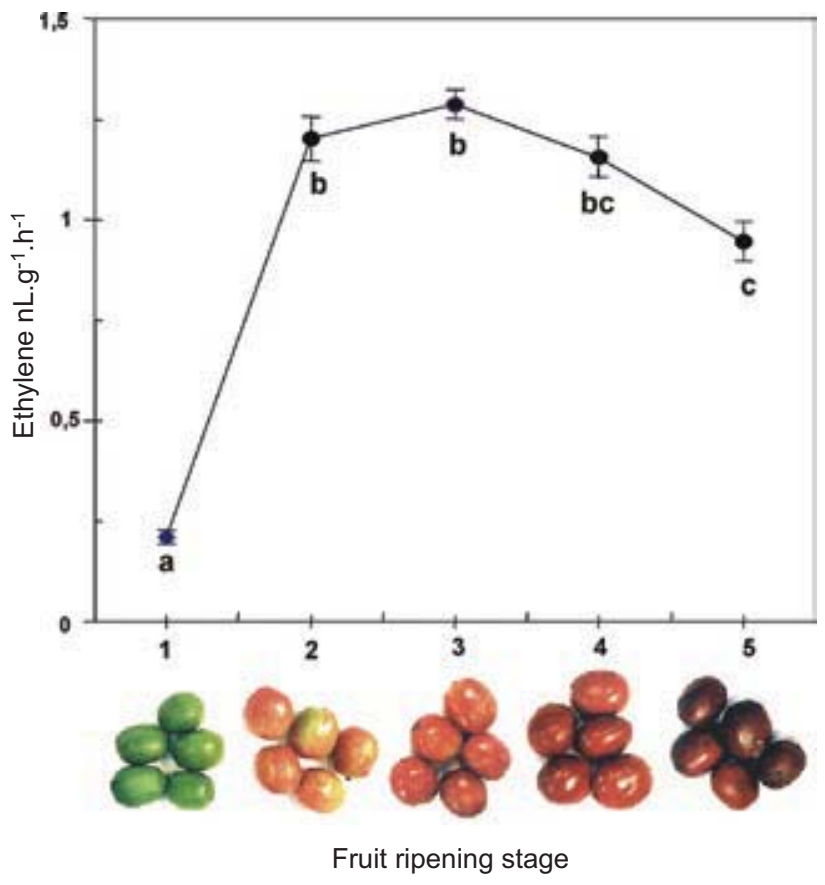

Figure 1. Ethylene production in C. arabica fruits during ripening. Ethylene production in coffee fruits was measured using gas chromatography. Bars represent standard errors of three replicates. Images below the $\mathrm{X}$-axis show the fruit ripening stages: 1) green; 2) yellow-red; 3) red; 4) cherry; 5) dark-cherry. Different letters indicate significant differences using the LSD (0.05) test.

A 965 bp cDNA fragment was amplified from coffee fruit RNA isolated at intermediate stages of ripening and cloned (figure 2). As expected, the cDNA is homologous with previously described $A C C$ oxidase cDNA in Coffea (Stiles et al., 1999) and was identified as $C a-A C O$. The nucleotide and amino acid deduced sequences of the clone showed high homology with ACO genes from Actinidia deliciosa, Carica papaya, Prunus persica and Plantago major, with 80 to 84 $\%$ of identity. As expected, all the fruit species showing such high homology are classified as climacteric. A phylogenetic tree formed with 14 other ACO amino acid sequences grouped most ACOs from climacteric fruits (figure 3).

ACO is usually encoded by a small multigene family. Similar to the ACC synthase gene family, possibly each family member of ACO plays a specific function. Although the Southern Blot analysis revealed the presence of only two genes in $C$. arabica (figure 4), a quick search in the recent EST database of Coffea (www.lge.ibi.unicamp.br/cafe/) showed that at least four genes are involved in the expression of $A C O$ (data not shown). Since the Southern blot was performed under high stringency conditions, reduced stringency hybridization 


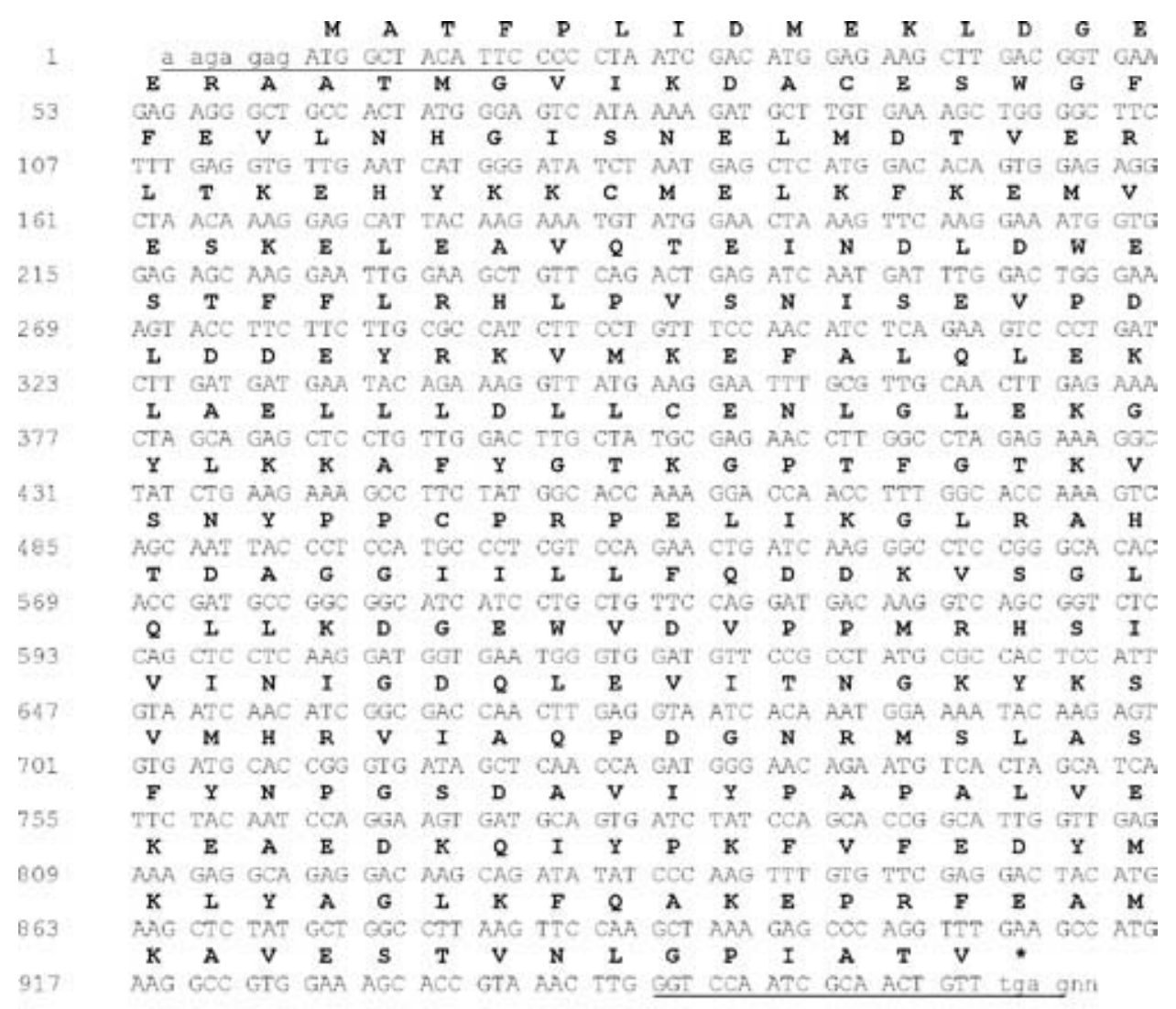

Figure 2. $C a-A C O$ cDNA sequence from $C$. arabica and the translated protein amino acid sequence. cDNA was obtained from the mRNA of yellow/red fruits. Primer sequences used to amplify the gene are underlined.

and membrane washings might reveal those genes (Neupane et al., 1999). The similar band pattern found in the three species analyzed is in agreement with the commonly accepted origin of the allotetraploid $C$. arabica, resulting from the natural hybridization of $C$. canephora and $C$. eugenioides followed by chromosome duplication (Lashermes et al., 1999).

Analysis of $C a-A C O$ transcripts showed different expression levels in all tested tissues (figure 5). $\mathrm{Ca}-\mathrm{ACO}$ transcripts were detected mainly in fruits and barely detected in shoots and mature leaves. No hybridization was observed in young leaves and roots. $C a-A C O$ transcripts were also detected during the development of flower buds. Barry et al. (1996) also demonstrated an increase of $A C O$ transcripts during tomato flower development. The analysis of $C a-A C O$ transcripts during fruit maturation showed the lowest expression of the gene at early ripening stages (green color), followed by an increased level of transcription at later stages. Although preliminary data for $\mathrm{Ca}-\mathrm{ACO}$ expression studies by RT-PCR showed a decrease in transcription at the cherry stage (Galvão et al., 2001), the Northern blot results showed a similar expression of $C a-A C O$ after the green stage. Since there is a significant decrease ethylene production, one possible explanation for the continuous $C a-A C O$ expression is that post-transcriptional control mechanisms are involved in the regulation of either the transcript processing or the enzyme activity. The possibility of control of ACO through proteasome-mediated regulation has been reported for Arabidopsis, where mutants for a RUB1 (Related to UBiquitin) gene showed both overproduction of ethylene and ACO activity (Larsen and Cancel, 2004). Also, post-transcriptional control of ACS is related to the enzyme C-termini, the target for rapid enzyme inactivation or degradation due interaction with ETO1 protein via the ubiquitin-26S-proteasome pathway (Wang et al., 2004; Chae and Kieber, 2005). Phosphorylation of the C-termini avoids the interaction with ETO1, increasing the ACS stability (Liu and Zhang, 2004). Analyses of four Arabidopsis ethyleneoverexpressing mutants showed that this phenotype was related to the increased stability of ACS protein at their C-terminal region (Chae et al., 2003; Wang et al., 2004). Two of those mutants, eto 2 and eto 3 resulted from alteration of the conserved C-termini of an ACS gene (Chae et al., 2003). The eto 2 mutant lacks serine residues which are 


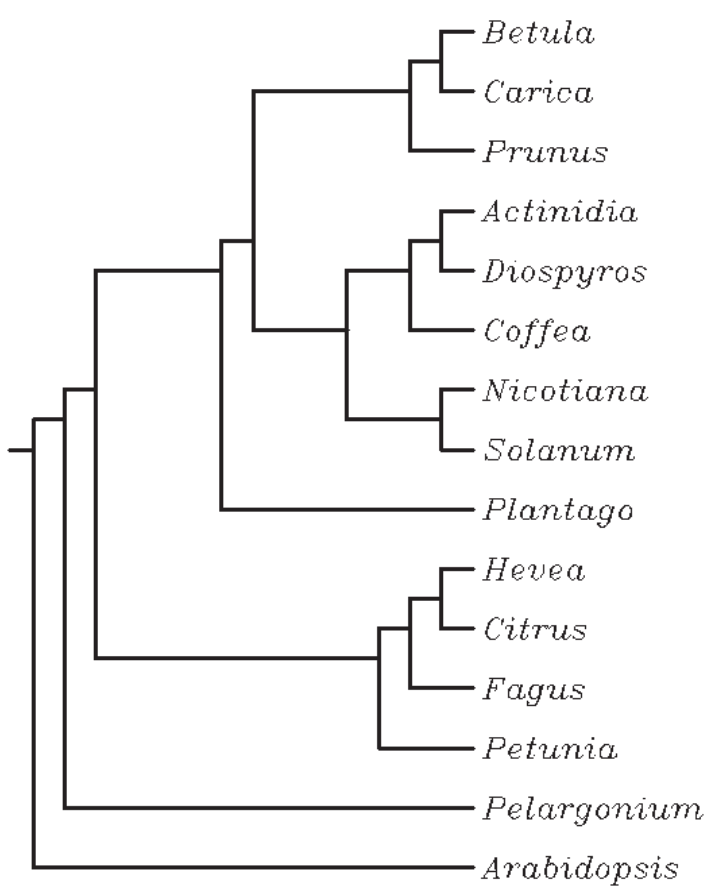

Figure 3. Phylogenetic dendrogram of Coffea ACC oxidase. Amino acid sequences were aligned using Clustal W 1.18 Multiple Sequence Alignments to create the dendrogram. Sequences were accessed at GeneBank NCBI as follows: Betula pendula CAA71738; Actinidia deliciosa AAA18566; Carica papaya CAE53415; Prunus persica AAF36484; Diospyros kaki BAB89352; Plantago major CAH58646; Solanum tuberosum AAK68076; Nicotiana tabacum CAA58232; Hevea brasiliensis AAP41850; Fagus sylvatica CAD21844; Citrus sinensis AAG49361; Petunia x Hibrida Q08507; Pelargonium x hortorum AAB70884; Arabidopsis thaliana CAA47251.

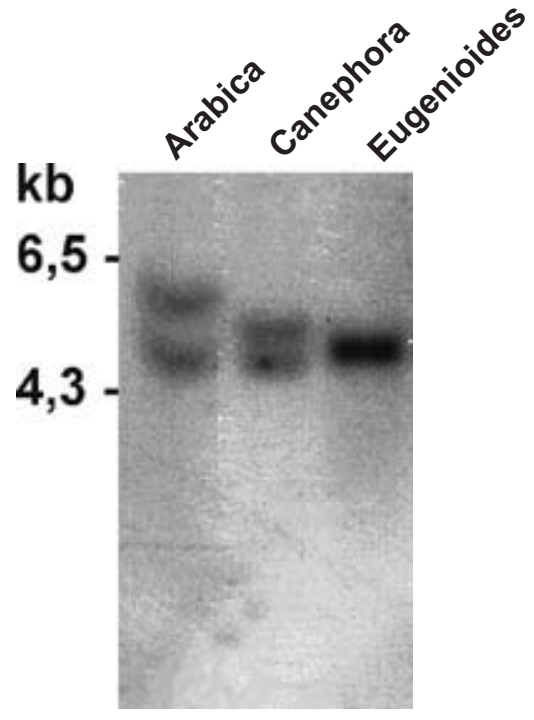

Figure 4. Southern blot analysis of Coffea ACO. DNA from different Coffea species was digested with EcoRI and hybridized with $C a-A C O$.
A
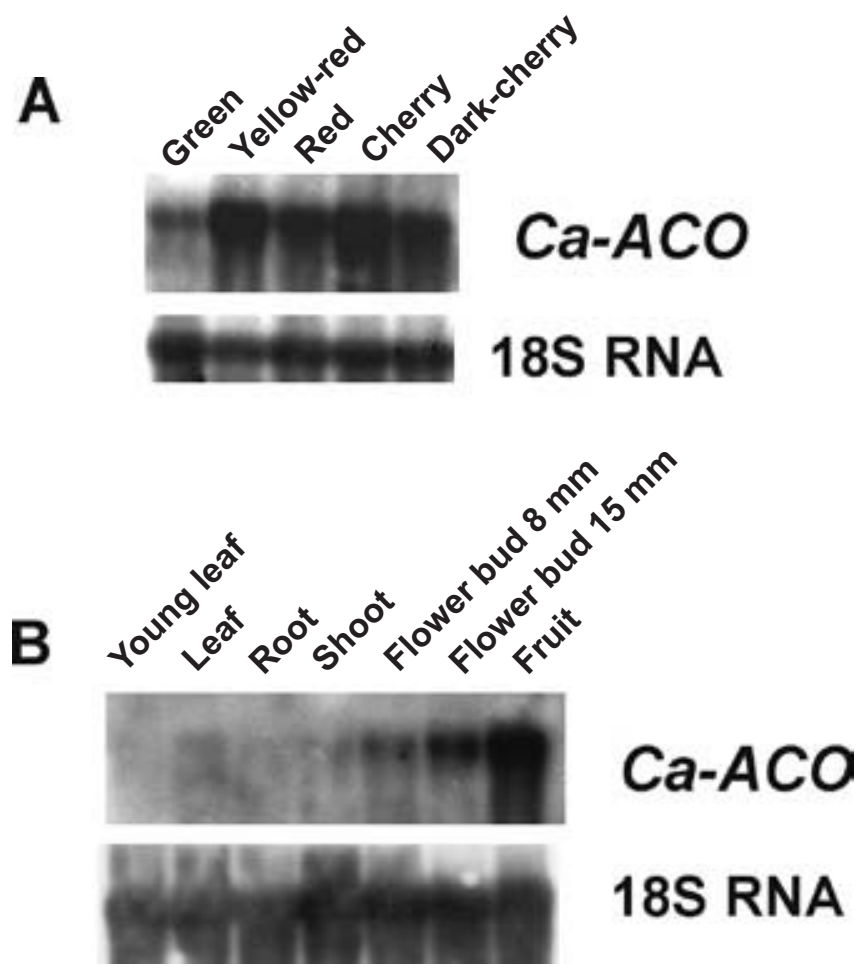

Figure 5. Northern blot analysis of total $C$. arabica RNA hybridized with $C a-A C O$. A) RNA from fruit pulp from different ripening stages. B) RNA from different coffee tissues as described. Blots were stripped and hybridized with an 18S rRNA probe as a loading control.

the targets for a calcium-dependent kinase and mitogenactivated protein kinase which may also be the target for the negative regulator ETO1 protein. The $\mathrm{C}$-terminal region of the deduced amino acid sequences of ACO from different species, including $\mathrm{Ca}-\mathrm{ACO}$, also reveals a pattern for serine residues which are hypothetical targets for phosphorylation (Figure 6), similar to the ones presented in ACS (Chae and Kieber, 2005). Further work on phosphorylation of ACO by specific kinases is required to confirm this mechanism of post-transcriptional control.

Ripening in climacteric fruits is characterized by major biochemical and physiological changes. There is a massive amount of ethylene production associated with an increase of respiration, which will lead to changes in gene expression. The physiological and molecular data presented here support the assumption for the climacteric nature of the coffee ripening process. Previous studies on coffee fruit respiration and enzymatic activity had indicated this hypothesis through an increase in respiration rates during fruit maturation, with a peak at the maximum ripening (Puschmann, 1975; Marian-Lopez et al., 2003). In addition, Puschmann (1975) 


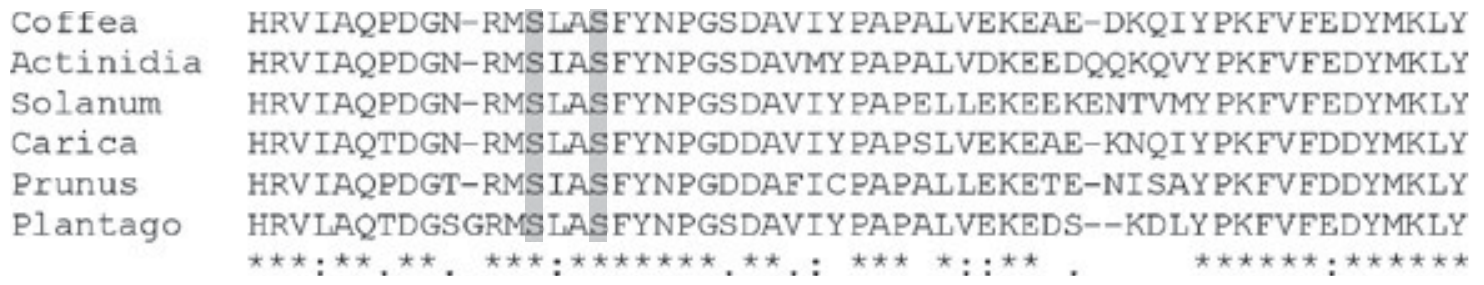

Figura 6. Comparison of the $\mathrm{C}$-terminal region of $\mathrm{ACO}$ enzymes. C-terminal region of $\mathrm{ACO}$ amino acid sequences were compared using clustal W Alignment. Serine residues which are predicted targets for phosphorylation are marked in grey.

demonstrated a fast increase in reducing sugars during ripening. Increased activities of glycosidases such as $\alpha$ and $\beta$-galactosidase, $\alpha$-mannosidase, galactosiminidase and glucosiminidase during ripening have been demonstrated (Golden et al., 1993). Among these, $\beta$-galactosidase produced the highest increase in activity during ripening. An increase in expression of the genes and enzymatic activity of pectinases and poligalacturonases has also been observed during the intermediate and the final stages of maturation, respectively (Pimenta et al., 2000; Cação et al., 2004).

To our knowledge, this is the first report showing ethylene production and the expression of a gene involved in its biosynthesis in coffee fruits. This association is a strong indication of climacteric type ripening for coffee fruits. We also observed that fruits at early stages of maturation, left in the sealed flasks, continued changing color after ethylene analysis (data not shown), which is another indication of the climacteric nature of fruits. Further work is currently under way to characterize respiration rate, ethylene production and expression of genes involved in ethylene biosynthesis as well as genes involved in the depolymerization of pectin and cell wall components. Genetic transformation of Coffea spp. with $C a-A C O$ in the antisense orientation has been carried out to study the physiology of fruit ripening in this important crop.

Acknowledgements: This research was supported by the Consórcio Brasileiro de Pesquisa e Desenvolvimento do Café (CBP\&D-Café) and by the CNPq/PADCT III. The authors wish to thank Dr. JCM Cascardo for sequencing Ca-ACO.

\section{REFERENCES}

Altschul SF, Gish W, Miller W, Meyers EW, Lipman DJ (1990) Basic local alignment search tool. J. Mol. Biol. 215:403-410. Balagué C, Watson CF, Turner AJ, Rouge P, Picton S, Pech JC, Grierson D (1993) Isolation of a ripening and woundinduced cDNA from Cucumis melo L. encoding a protein with homology to the ethylene-forming enzyme. Eur. J. Biochem. 212(1):27-34.
Barry CS, Blume B, Bouzayen M, Cooper W, Hamilton AJ, Grierson D (1996).Differential expression of the 1aminocyclopropane-1-carboxylate oxidase gene family of tomato. Plant J. 9:525-35.

Browning G, Fisher NM (1976) High density coffee yield results for the first cycle from systematic plant spacing designs. Kenya Coffee 41:209-218.

Camargo, AP (1985) Florescimento e frutificação do café arábica nas diferentes regiões cafeeiras do Brasil. Pesq. Agrop. Bras. 20:831-839.

Cação SMB, Galvão RM, Pereira LFP, Vieira LGE (2003).Identificação e caracterização de genes de poligalacturonase de Coffea arabica. In: Anais do III Simpósio de Pesquisa dos Cafés do Brasil. Porto Seguro, Bahia, Brazil 98-99.

Chae HS, Faure F, Kieber JJ (2003) The eto1, eto2, and eto3 mutations and cytokinin treatment increase ethylene biosynthesis in Arabidopsis by increasing the stability of ACS protein. Plant Cell 15:545-559

Chae HS and Kieber JJ (2005) Eto Brute? Role of ACS turnover in regulating ethylene biosynthesis. Trends Plant Sci. 10:291-296.

Chang S, Puryear J, Cairney J (1993) A single and efficient method for isolating RNA from pine trees. Plant Mol. Biol. Rep.11:113-116.

Galvão RM, Kobayashi AK, Ribas AF, Bespalhok Filho JC, Pereira LFP, Vieira LGE (2001) Identificação e caracterização de genes de ACC oxidase de café. In: Anais do II Simpósio de Pesquisa dos Cafés do Brasil, Vitória, ES, Brasil pp.32-33.

Golden KD, John MA, Kean EA (1993) $\beta$-Galactosidase from Coffea arabica and its role in fruit ripening. Phytochemistry 34:355-360.

Majerowicz N, Söndahl, MR (2005) Induction and differentiation of reproductive buds in Coffea arabica L. Braz. J. Plant Physiol. 17:247-254.

Hamilton AJ, Lycett GW, Grierson D (1990) Antisense gene that inhibits synthesis of the hormone ethylene in transgenic plants. Nature 346:284-287.

Knoester M, Linthorst HJM, Bol JF, Loon LC (1997) Modulation of stress-inducible ethylene biosynthesis by sense and antisense gene expression in tobacco. Plant Sci. 126:173-183.

Larsen PB, Cancel JD (2004). Loss-of-Function Mutations in the Ethylene Receptor ETR1 Cause Enhanced Sensitivity and Exaggerated Response to Ethylene in Arabidopsis. Plant J. 38:626-638 
Lashermes P, Combes MC, Robert J, Trouslot P, D'Hont A, Anthony F, Charrier A (1999) Molecular characterization and origin of the Coffea arabica L. genome. Mol. Gen. Genet. 261:259-266.

Lin CT, Lin MT, Shaw JF (1997) Cloning and Characterization of a cDNA for 1- Aminocyclopropane-1-Carboxylate Oxidase from papaya fruit. J. Agric. Food Chem. 45: 526-530.

Liu YD and Zhang SQ (2004) Phosphorylation of 1-aminocyclopropane-1-carboxylic acid synthase by MPK6, a stress-responsive mitogen-activated protein kinase, induces ethylene biosynthesis in Arabidopsis. Plant Cell 16: 3386-3399.

Lopez-Gomez R, Morales-Dominguez F, Mendoza Alcazar O, Gomez-Lim MA (2004) Identification of a genomic clone to ACC oxidase from papaya (Carica papaya L.) and expression studies. J. Agric. Food Chem. 52:794-800.

Marin-Lopez SM, Arcila PJ, Montoya REC, Oliveros TCE (2003) Cambios físicos y químicos durante la maduración del fruto de café (Coffea arabica L. var. Colombia). Cenicafé 54:208-225.

Neupane KR, Moisyadi S, Stiles J (1999) Cloning and characterization of fruit-expressed ACC synthase and ACC oxidase from coffee. In: Proceedings of the $18^{\text {th }}$ ASIC Colloquium. Helsinki, Finland, pp. 322-326.

Pimenta CJ, Chagas SJR, Costa L (2000) Pectinas e enzimas pectinolíticas em café (Coffea arabica L.) colhido em quatro estádios de maturação. Ciênc. Tecnol. 24:1079-183.

Puntervoll P, Linding R, Gemünd C, Chabanis-Davidson, S., Mattingsdal, M., Cameron, S, Martin, DMA, Ausiello G, Brannetti B, Costantini A, Ferrè F, Maselli V, Via A, Cesareni G, Diella F, Superti-Furga G, Wyrwicz L, Ramu C, McGuigan C, Gudavalli R, Letunic I, Bork P, Rychlewski ., Küster B, Helmer-Citterich M, Hunter WN, Aasland R, \& Gibson T J (2003) ELM server: a new resource for investigating short functional sites in modular eukaryotic proteins. Nucleic Acids Res. 31:3625-3630.

Puschmann R (1975) Características bioquímicas dos frutos do cafeeiro (Coffea arabica L.) durante a maturação. Viçosa, Minas Gerais, Brazil, University of Viçosa. MSc thesis.

Rena AB, Nacif AP, Pereira AA (1994) Fisiologia de cafeeiro em plantios adensados. In: Anais do Simpósio Internacional sobre Café Adensado, Londrina, PR, Brazil, pp.320.

Stiles J, Moisyadi I, Neupane KR (1999) Purified proteins, recombinant DNA sequences and processes for controlling the ripening of coffee plants. USA patent 5,874,269.

Song JD, Kim JH, Lee DH, Rhew TH, Cho SH, Lee CH. (2005) Developmental regulation of the expression of 1aminocyclopropane-1-carboxylic acid (ACC) synthase and ACC oxidase genes in hypocotyls of etiolated mung bean seedlings. Plant Sci. 168:1149-1155

Thompson JD, Higgins DG, Gibson TJ (1994) CLUSTAL W: improving the sensitivity of progressive multiple sequence alignment through sequence weighting, positionspecific gap penalties and weight matrix choice. Nucleic Acids Res. 11:4673-80.

Wang KL, Li H, Ecker JR (2002) Ethylene biosynthesis and signaling networks. Plant Cell 14:S131-S151.

Wang KLC, Yoshida H, Lurin C, Ecker JR (2004) Regulation of ethylene gas biosynthesis by the Arabidopsis ETO1 protein. Nature 428:945-950.

Whittaker DJ, Smith GS, Gardner RC (1997) Expression of ethylene biosynthetic genes in Actinidia chinensis fruit. Plant Mol. Biol. 34:45-55.

Yang SF, Hoffman BE (1984) Ethylene biosynthesis and its regulation in higher plants. Annu. Rev. Plant Physiol. 35: 155-189.

Yang SF (1987) Regulation of biosynthesis and action of ethylene. Acta Hort. 201:53-59. 